Zbiegeń-Maciąg, L. (Ed.) (2008). Społeczna odpowiedzialność biznesu, a zarządzanie talentami [Corporate social responsibility and talent management]. Organizacje w gospodarce innowacyjnej - aspekty społeczne, prawne, psychologiczne [Organizations in innovative economy - social, legal, and psychological aspects]. Kraków: AGH, 37.

43. Listwan, T.; in: Borkowska, S. (2005). Zarzadzanie talentami - wyzwania współczesnych organizacji [Managing talents - the challenges of modern organizations], 21 .

44. In: FOB Raport Odpowiedzialny Biznes w Polsce w 2002 roku [FOB Report - Responsible Business in Poland in 2002] (2003). Warsaw: FOB, 5. In: Katechizm Kościoła Katolickiego (1994). Poznań: Pallotinum, 437.

45 Sosińska, N. (2007). Magia rozwoju talentów [The magic of talent development]. Kraków: IFC Press, 15.

46. Sienkiewicz, H. (1978). Janko Muzykant [Janko the Musician] Vol. 1. Warsaw: PIW, 294.

47. Makarenko, A. S. (1949). Izbrannyje piedagogiczeskije soczynienija. Moscow, 130.

48. Fliegler, L. A. (1961). Curriculum planning for the gifted. Prentice-Hall, 31.

49. Kotarbiński, T. (1969). Traktat o dobrej robocie [Praxiology. An introduction to the science of efficient action] 4th edition. Wrocław: Ossolineum, 213.

50. Plato (1958). The Republic. Book IV. Warsaw,

51. Janowski, A. (2007). Kompetencje agentów ubezpieczeniowych a efektywność towarzystw ubezpieczeń na życie [Competencies of life insurance agents and the effectiveness of life insurance companies]. Unpublished doctoral thesis. Warsaw: Instytut Orgmasz, 146, 149.

52. Lyotard, J. F. (1971).; as quoted in: M. Vogt (2004).
Kondycja ponowoczesna. Raport o stanie wiedzy [The Postmodern Condition: A Report on Knowledge]. Historia filozofii (History of philosophy) Warsaw: KDC, 407.

53. Plato (1956). Polityk [Statesman]. Warsaw: PWN, 284D, 156. Available at: http://www.perseus.tufts.edu/hopper/ text?doc=Perseus\%3Atext\%3A1999.01.0172\%3Atext\%3DStat. \%3Asection\%3D284d (Last accessed: 22 December 2014).

54. Plato (1956). Polityk [Statesman]. Warsaw: PWN, 285A. Available at: http://classics.mit.edu/Plato/stateman.html (Last accessed: 22 December 2014).

55. Anderson, G. C. (1993). Managing Performance Appraisal Systems. Oxford: Blackwell.

56. McKenna, E., Beech, N. (1997). Zarządzanie zasobami ludzkimi [Human resource management]. Warsaw: Gebethner i S-ka, 153.

57. Pocztowski, A. (1996). Zarządzanie zasobami ludzkimi [Human resource management]. Wrocław: Ossolineum, 125.

58. Smyk, E.; in: Rybak, M. (Ed.). Znaczenie oceniania w kształtowaniu rozwoju pracowników [The importance of evaluation in promoting employee development]. Zarządzanie kapitałem ludzkim $\mathrm{w}$ przedsiębiorstwie [Human capital management in an enterprise]. In: Monografie i opracowania [Monographs and studies]. Vol. 470 (IFGN 41). Warsaw: SGH, 162.

59. Sloman, M. Strategia szkolenia pracowników [A handbook of employee training strategy]. Warsaw: PWN, 142.

60. Dante (2002). De Monarchia. Warsaw: Antyk. Chapter XIII, 1. Available at: http://oll.libertyfund.org/titles/ 2196 (Last accessed: 22 December 2014)

Дата надходження рукопису 15.01.2015

Błażej Balewski, PhD, Dean of Faculty of Economics, Wyższa Szkoła Kadr Menedżerskich, ul. Zagórowska, 3a, Konin, Poland, 62-500

E-mail: blazej@balewski.pl

УДК 336.018: 330.162

DOI: $10.15587 / 2313-8416.2015 .37410$

\title{
ПЕРЕДУМОВИ СОЦІАЛІЗАЦІЇ ФІНАНСІВ ТА ПРИНЦИПИ ФОРМУВАННЯ МОДЕЛІ ФІНАНСОВИХ ВІДНОСИН В УМОВАХ СТАЛОГО РОЗВИТКУ
}

\section{(C) І. П. Васильчук}

Досліджено аспекти соціалізації економіки і фінансів під впливом парадигми сталого розвитку. На підставі теоретичного аналізу виявлено домінантні чинники постіндустріальної трансформації фінансових відносин, зокрема сочіалізація, демократизація, коллаборація та конвергенція. Запропоновані принщипи побудови оновленої моделі фінансових відносин в умовах сталого розвитку

Ключові слова: сталий розвиток, сочіалізація фінансових відносин, демократизація, коллаборація, конвергенція, соціальні фінанси

The article investigates the aspects of socialization of economics and finance in course of the emergence of the sustainable development paradigm. The theoretical analysis which was conducted in the article has identified the dominant factors for post-industrial transformation of financial relations, such as socialization, democratization, collaboration and convergence. Besides, the author derives several principles for the construction of the revised model for financial relations in the context of sustainable development

Keywords: sustainable development, socialization of financial relations, democratization, collaboration, convergence, social finance

\section{1. Вступ}

Поглиблення суперечностей ринкової економіки, наростання глибоких екологічних проблем планети, посилення соціальної нерівності у суспільстві, триваюча економічна рецесія призводять до розуміння широким загалом людства нездатності традиційної економічної політики розв'язати ці проблеми. Все наполегливіше висловлюються думки про необхідність 
радикальної перебудови еконо-мічної системи капіталізму на нових засадах. Зокрема, в своїй статті «Капіталізм і фінансові інновації» Нобелівський лауреат Шиллер P. (Shiller, 2013) висловлює свою точку зору і зазначає, що останні опитування громадської думки свідчать про падіння підтримки капіталізму у всьому світі. Тому капіталізм, на його думку, як найкращий винахід сучасного соціально-економічного устрою, має змінитися [1]. Зазначимо, що проблеми та особи-вості трансформації капіталізму $\epsilon$ достатньо дослі-дженими в теорії та сформовані різні концепції (технологічного детермінізму, глобалізації й екологізації економіки, соціального ринкового господарства, соціалізації капіталу та гармонізації соціальноекономічних відносин тощо), але наслідки останньої фінансово-економічної кризи спричинили сплеск зацікавленості з боку наукової спільноти до теорій i концепцій, які пов'язані із соціалізацією економічних відносин в умовах переходу до постіндустріальної економіки. Соціалізація економі-ки, зміна ціннісних орієнтирів суспільства спричиняють і соціалізацію фінансових відносин.

\section{2. Постановка проблеми}

Поняття «соціальна економіка», «соціальноорієнтована ринкова економіка» не є новими для сучасної економічної теорії, але в останні кілька років ці терміни все активніше використовуються не тільки в суспільно-політичних дебатах, а й дедалі частіше опиняються в колі уваги академічних досліджень. Цей факт можна вважати ознакою досягнення критичної стадії розвитку традиційного мислення та формування нової економічної парадигми. I якщо аспекти форми, принципів, закономірностей формування нового господарсько-економічного устрою постіндустріального періоду ще не набули завершеного дослідження і потребують суттєвих наукових дискусій, то вектори розвитку такої економіки вже визначені - економічна, екологічна та соціальна відповідальність бізнесу, переосмислення ролі і мотивації поведінки людини та соціуму, природи відносин власності та зміна парадигми економічного зростання. Найкраще відповідає запитам соціальної економіки людино-центрична парадигма, що визначає і напрямки парадигми сталого розвитку. Не дивлячись на значну кількість наукових публікацій щодо різних аспектів сталого розвитку, їх аналіз виявив, що на вітчизняних теренах сформувався переважно еколого-орієнтований підхід до розуміння сутності сталого розвитку і мало уваги приділяється його соціальній складовій. Крім того, недостатньо дослідженими $є$ аспекти соціалізації фінансів під впливом парадигми сталого розвитку.

Мета статті - на підставі теоретичного аналізу виявити домінантні чинники постіндустріальної трансформації фінансових відносин та сформулювати принципи побудови оновленої моделі фінансивих відносин в умовах сталого розвитку.

\section{3. Огляд літератури}

У вітчизняній фаховій літературі сформований науковий підхід до розуміння сутності та чинників соціалізації економіки як органічної ланки загального процесу соціалізації. Насамперед, наведемо позицію А. С. Гальчинського, який, досліджуючи природу економічних відносин, зазначає, що «економічні відносини $\epsilon$, природно, також i соціальними, i психологічними, i моральними, i політичними та іншими відносинами, тобто подібними до всіх суспільних відносин, через механізми яких люди взаємодіють як один з одним, так і з природою» [2]. Автор визначає економіку як невід'ємну (соціальну) складову суспільства і наголошує, що «економіка, як соціальна система, втілює себе через структурну подвійність своїх функціональних форм. Така подвійність розглядається як субстанціональна ознака економічних процесів. Товар, гроші, капітал, як і будь яка інша економічна категорія, мають, 3 одного боку, природно-речові, а з іншого - соціальні (суто економічні) характеристики» [2]. Отже, маємо беззаперечну думку, що економічні відносини $\epsilon$ соціальними. Проте, на нашу думку, рівень соціалізації економіки за різних укладів та на різних етапах розвитку суспільства $\epsilon$ різним, що i підтверджується посиленням тенденцій соціалізації в постіндустріальний період та становленням нового типу соціально-економічних відносин. Вітчизняні вчені Ю. К. Зайцев, В. С. Савчук відстоюють думку, що соціалізація економіки виявляється у становленні та розвитку тенденції, а згодом і закономірності, згідно 3 якою під впливом потреб виробництва відчутно прискорюється процес засвоєння та використання основними суб'єктами господарювання (у своїх інтересах) специфічної системи знань, норм i цінностей, необхідних для успішного функціонування ї в системі суспільного відтворення, а отже, в системі соціально-економічних відносин [3]. Автори визнають соціальну компоненту як важливу складову економічного зростання, врахування якої забезпечує сталий розвиток та економічний прогрес. Нашому розумінню сутності процесів соціалізації економіки відповідає позиція Колота А. М., який постулює, що «економічному розвитку завжди притаманні соціальні наслідки, тобто він соціальний за природою» [4]. Автор наголошує на тісному переплетенні соціального й економічного аспектів суспільного розвитку та на першорядній значущості соціального розвитку. Таким чином, більшість вчених пов'язують цільову орієнтацію економіки нового типу з задоволенням потреб усіх членів суспільства. Щодо поняття «соціально-орієнтована економіка», яке найчастіше використовується вітчизняними науковцями, існує його поширене тлумачення як економіки, що своїм першочерговим завданням бачить забезпечення стабільного розвитку суспільства в цілому, задоволення насущних потреб людей, гармонізацію взаємин між різними соціальними групами [4]. Розвиток соціалізації економіки на макрорівні неможливий без соціалізації господарства на мікрорівні, насамперед на рівні корпорацій. Зокрема, Ю. М. Уманців під соціалізацією на рівні корпорації розуміє процес урівноваження інтересів усіх акціонерів та координацію інтересів корпорації 3 
усіма зацікавленими сторонами, що співпрацюють [5]. А. В. Сірко акцентує увагу на тому, що корпораціям, як найбільш досконалій організаційній формі економічних відносин, властивий високий рівень соціалізації. Саме ця риса характеризує корпорацію як інституціональну форму вирішення суперечностей розвитку приватновласницької системи господарювання [6]. Можна цілком згодитися 3 наведеними аргументами щодо важливості врахування соціальних аспектів сталого розвитку та зростання рівня соціалізації економіки у постіндустріальний період. По суті, сочіалізація економіки означає визнання сочіального чинника імперативом сталого економічного розвитку у постіндустріальний період, поряд $з$ імперативом захисту навколишнього середовища як умови виживання людства. Усвідомлення необхідності враховувати і збалансовувати інтереси всіх членів суспільства в однаковій мірі та створення умов для гармонійного розвитку індивіда як носія та одиниці універсуму людського, інтелектуального та соціального капіталу має стати основою формування ідеології і принципів соціальної економіки.

\section{4. Передумови та принципи формування} моделі фінансових відносин в умовах сталого розвитку

Аналіз фахової літератури та останніх тенденцій економічного розвитку виявив посилення тенденцій сочіалізації, демократизащії, коллаборації ma конвергениіï, що дозволило виділити їх як домінантні серед основних чинників постіндустріального сталого економічного розвитку, які зумовлюють зміни та визначають особливості формування фінансових відносин в соціальній економіці. Поширення та поглиблення тенденцій дозволяє виділяти їх як закономірності розвитку, що, в свою чергу, уможливлюе визнання їх принципами функціонування економіки на засадах сталого розвитку.

Дослідження сутності дефініції дозволило 3'ясувати, що під соціальною економікою в світовій практиці традиційно розуміють частину економіки, яка не $\epsilon$ приватною або державною і включає в себе соціальні підприємства, а також добровольчі організації, фонди, профспілки, релігійні установи і об'єднання ЖКГ [7]. В такому трактуванні до соціальної економіки відносять функціонування окремого сектору економіки - соціального сектору, структура якого $є$ досить усталеною. Проте прийняття парадигми сталого розвитку змінило підходи і на сьогодні відбувається трансформація цього сектору та його економічних основ функціонування, насамперед, на засадах суспільної солідарності, коллаборації та конвергенияї. Саме тому виникає необхідність перегляду сутнісного наповнення поняття «соціальна економіка» та розгляду його в новому контексті. Соціальна економіка в контексті оновленої парадигми як економіки суспільної солідарності та коллаборації зародилася i поступово розвивається на протязі останніх десяти років. На сьогодні вона найбільш розвинута в США і Великобританії, але і в цих країнах ще $\epsilon$ далекою до справжньої зрілості. На думку практиків соціальна економіка не обов'язково передбачає наявність високо розвинутого ринку i можливостей розвинутої інвестиційної економіки. Головним чинником іiї становлення $є$ рівень розвитку інститутів громадянського суспільства [8]. Становлення соціальної економіки та фінансів неможливо без соціальної відповідальності держави, бізнесу, соціуму та індивіда, поширення якої $є$ свідченням зрілості громадянського суспільства. Тому, на нашу думку, корпоративна соціальна відповідальність повинна визнаватися як нормативний імператив поведінки бізнесу у постіндустріальному суспільстві, необхідною умовою і ідеологією сталого розвитку та чинником формування соціальної економіки. Таким чином, 3 необхідної передумови та чинника становлення сочіалізачія перетворюеться $у$ основоположний принции побудови нової сочіальної економіки в умовах сталого розвитку.

Немаловажним чинником становлення соціальної економіки і моделі фінансових відносин нового типу є коллаборативний принциип взаємодії між учасниками економічних відносин, які формують певну мережу. Аналіз фахової літератури та фактологічних даних дозволяє виділити зародження нового теоретичного підходу до визначення рушійних сил економічного розвитку, за якого конкуренція перестає бути домінуючим фактором, а на противагу їх приходить коллаборація. Прихильники нового коллаборативного підходу, піддаючи критиці пануючу парадигму, опонують, що «після близько тридцяти років домінування (Friedman, 1970; Porter, 1979; Rappaport, 1986), які і раніше, переважає модель конкурентної економіки, яка характеризується вузькою спрямованістю на грошові (монетарні) результати та короткострокові рішення i цей руйнівний підхід, який приносить вигоди меншості (особливо фінансовим інвесторам та топменеджерам) за рахунок більшості (включаючи суспільство в цілому, місцеві громади, екосистеми та послуги, майбутні покоління) сьогодні піддається критиці [9]. На їх думку діюча модель конкурентної економіки потребує фундаментальної корекції, що дозволить корпораціям розвивати дійсно сталі та відповідальні способи ведення бізнесу. Варто нагадати, що у своїй більш пізній праці «Створення спільних цінностей» М. Портер та М. Креймер (Porter, Kramer, 2011) [10] відійшли від власної раніше жорсткої позиції щодо визнання конкурентоспроможності компанії домінантним чинником створення іiі вартості та представили розвиток власної концепції, за якої створення вартості залежить від чинників усталеності відносин зі стейкхолдерами. Цю саму ідею (стейкхолдерський підхід) відстоюють і розвивають в нинішній час переважна більшість провідних вчених. Зазначимо, що стейкхолдерський підхід отримав подальший розвиток і поступово трансформується у модель економіки, засновану на співпраці (коллаборативна модель). Основними адептами коллаборативного підходу можна назвати вчених А. Тенкаті, Ф. Пер- 
рині, Л. Жолнай, С. Погуц (Tencati, Perrini, Pogutz, 2004; Tencati, Zsolnai, 2013), які послідовно досліджують прояви та особливості нового підходу, його практичну реалізуємість, що дозволило їм виділити особливості та відміни між двома моделями (табл. 1).

Таблиця 1

Конкурентоспроможність проти коллаборації

\begin{tabular}{|c|c|c|}
\hline Характеристики & $\begin{array}{c}\text { Модель } \\
\text { конкуренції }\end{array}$ & $\begin{array}{c}\text { Модель } \\
\text { коллаборації }\end{array}$ \\
\hline мотив & Користь & $\begin{array}{c}\text { Турбота про } \\
\text { інших і самих } \\
\text { себе }\end{array}$ \\
\hline Основна ціль & $\begin{array}{c}\text { Максимізація } \\
\text { прибутку або } \\
\text { акціонерної } \\
\text { вартості }\end{array}$ & $\begin{array}{c}\text { Створення } \\
\text { вартості для } \\
\text { всіх учасників } \\
\text { мережі }\end{array}$ \\
\hline Критерії успіху & $\begin{array}{c}\text { Зростання в } \\
\text { грошовому } \\
\text { вираженні }\end{array}$ & $\begin{array}{c}\text { Взаємовигідні } \\
\text { відносини із } \\
\text { зацікавленими } \\
\text { сторонами }\end{array}$ \\
\hline
\end{tabular}

Джерело: [9]

Захищаючи вигоди нового коллаборативного підходу А. Тенкаті та Л. Жолнай аргументують, що люди, які за своєю суттю вмотивовані дотримуватися етичних норм, часто процвітають в конкурентному середовищі. Водночас, соціально-відповідальні компанії отримують винагороду за більш високої вартості піклування, що проявляється у зниженні напруги агентського конфлікту та уникненні опортуністичної поведінки в парі «менеджервласник»; можливості залучення нових працівників 3 високим рівнем фаху; отримання лояльності споживачів та довіри субпідрядників тощо. На думку вчених, по-справжньому хороші компанії $\epsilon$ поза конкуренцією, обслуговуючи численні потреби їх мережі стейкхолдерів [9]. Дослідження встановило появу численних проявів коллаборації та посилення цих тенденцій. Можна навести декілька прикладів:

1) бурхливий розвиток обмінної (спільної) економіки, яка передбачає спільну власність на речі (каршерінговий бізнес (від англ. Share - частка; Carsharing - спільне володіння автомобілями), шерінгове житло та багато інших речей у спільному володінні і користуванні);

2) формування різного роду добровільних мережевих взаємодій у спільному розв'язанні проблем, зокрема і місцевих громад, коли інформація поширюється всередині мережі користувачів і збирає волонтерів (найкращим прикладом в Україні $\epsilon$ волонтерський рух на підтримку захисників країни у триваючому збройному конфлікті на Сході України);

3) створення добровільної мережі різнопрофільних компаній, об'єднаних метою створювати суспільне благо - рух «В-corp», поширений у США;

4) формування засад управління у сучасних мережевих корпораціях на принципі адхократії тощо.

Стосовно коллаборації у фінансових відносинах можна навести наступні приклади:

1) спільне фінансування різного роду проектів за допомогою механізму краудфандінгу;
2) заснування мережі соціально-вмотивованих інвесторів - фінансових установ, наприклад, такої як Глобальна мережа імпакт-інвестування (англ. Global Impact Investing Network, GIIN);

3) розробка новітніх спеціальних фінансових інструментів, таких як SIB (Social Investment Bonds), у співпраці держави, фінансових установ та соціальних організацій для реалізації програм державно-приватного партнерства.

Окрім спільної взаємодії співпраця має здійснюватися на засадах суспільної солідарності, що створює додаткові вигоди за рахунок рівної відповідальності кожного та спільної відповідальності перед наступними поколіннями. Проведені численні експериментальні й емпіричні дослідження (у тому числі і методами теорії гри) довели факт, що більшість людей справді готові скооперуватися щодо певної добровільної діяльності заради суспільного блага, але вони готові співробітничати тільки за умов, що й інші люди будуть робити те ж саме, тобто не хто не хоче бути «відщепенцем». За результатами експерименту «Intergenerational Goods Game» щодо пошуку відповіді на питання: «Як приймати альтруїстичні рішення сьогодні, які принесуть вигоду людям завтра?», було встановлено, що в той час, як $є$ меншість людей, яка не хоче співробітничати, більшість голосує альтруїстично, при цьому вони не голосують, щоб максимізувати їх власну вигоду. Цей факт, на думку дослідників, і надає можливість співробітництва на благо майбутнього [11].

Таким чином, наступний принции, на якому має грунтуватися економіка сталого розвитку сочіальна економіка - та модель фінансових відносин є коллаборачія на засадах суспільної солідарності. На нашу думку, економічні відносини на принципах коллаборативної взаємодії слугують підтвердженням осуспільненості цих відносин та надають підтердження людиноцентричній парадигмі.

Наступна визначальна тенденція, яка все настійливіше простежується у різноманітних фактах економічної діяльності, є подальша демократизація фінансових відносин та укорінення принципів демократії в управління економічними системами на різних рівнях ієрархії. 3 усього загалу існуючих тлумачень сутності процесу демократизації найбільш точно відображають зміст, який ми вкладаємо в це поняття, наступні:

1) процес поширення чого-небудь у всіх верствах суспільства [12];

2) процес, спрямований на подолання ієрархії керівництва в різних організаціях завдяки встановленню порядку, що передбачає участь кожного в управлінні шляхом запровадження системи голосування [13];

3) процес поширення принципів демократії [14].

В контексті фінансових відносин ми розуміємо демократизацію фінансів як процес забезпечення умов доступності фінансів до широкого загалу, зокрема i за рахунок скорочення ієрархії посередників через механізм прямого фінансування й інвестування. Ми вбачаємо наступні причини посилення процесів демократизації: 
1) падіння довіри до фінансових установ, насамперед, до банків, в т.ч. інвестиційних, та інших фінансових посередників, поштовхом до якого була остання фінансово-економічна криза. В сьогоднішніх умовах в світі в цілому та в Україні зокрема можна вести мову про всезагальну кризу довіри. Ця ситуація змушує людей шукати інші методи для отримання доступу до фінансових ресурсів.

2) розширення технічних можливостей за рахунок новітніх інформаційно-комунікаційних технологій, що дозволяють отримати миттєвий і прямий доступ до фінансування. Таким чином, формуються технічні передумови для демократизації фінансів.

3) зростання суспільної свідомості та обізнаності, що дозволяє індивідам самостійно обирати об'єкти вкладання грошових коштів чи фінансування виходячи 3 власних переваг та системи цінностей. Отже, визначається мотив для здійснення фінансових операцій.

Таким чином, в наявності є методи, мотиви, технічні передумови, що в сукупності і обумовлюють посилення процесів демократизації фінансів. На підставі спостережень висуваємо тезу, що процес демократизаиї фінансів призводить до посилення изентробіжних тенденцій, щзо спричиняє дезінтермедіацію фінансових послуг. Яскравим результатом взаємодії сукупності процесів демократизації, соціалізації i коллаборації $\epsilon$ поява феномену краудфандінгу. Не можна обійти i роль демократизації, зокрема використання такого іiі інструменту як система голосування, у підтримці сталого розвитку. За результатами вищезгаданого експерименту «Intergenerational Goods Game» отримано, що у разі прийняття рішень щодо збереження ресурсів для майбутніх поколінь на індивідуальному рівні, наявність спільних пулів ресурсів різко зменшується 3 плином часу; а при введенні демократичних інститутів голосування разюче покращується здатність до сталого розвитку [15]. Таким чином, автори проекту роблять висновок, що голосування має бути обов'язковим для всіх гравців з метою досягнення високих рівнів сталого розвитку. Крім того, автори емпірично обгрунтовують, що країни з демократичним устроєм мають більш високий рейтинг в Індексі Сталого розвитку в частині енергетичної політики, ніж країни 3 авторитарним та змішаним режимом. Як підсумок слід зазначити, що результати експерименту в певній мірі можуть слугувати підтвердженням тези щодо поширення процесів демократизації фінансів та необхідності побудови моделі оновлених фінансових відносин в умовах сталого економічного розвитку на принципах демократіі, які довели свою результативність.

Дослідження процесів трансформації фінансивих відносин дозволило виявити також і посилення тенденцій всеохоплюючої конвергениії, яка має перетворюючі властивості. Внаслідок процесів конвергенції створюються абсолютно нові продукти (організаційні, технологічні, інфраструктурні, фінансові тощо) з характеристиками формуючих складових, але завдяки синергетичному ефекту гібридний продукт найкраще відповідає тим запитам, які i зумовили його створення. Зокрема, з'являються нові форми фінансових інструментів, відмінних за мотивацією та цільовими орієнтирами; нові фінансові продукти з особливими характеристиками; нові організаційно-правові форми корпорацій $з$ розширеними можливостями, поступово розми-вається межа між державними, публічними та приватними фінансами тощо. Поява нових фінансових інструментів призводить до нового етапу у акумуляції ресурсів приватного сектору, яку можна зрівняти 3 початковими етапами становлення фінансів завдяки можливостям, які отримали підприємці та бізнес. Стало можливим отримувати і концентрувати значні суми фінансового капіталу завдяки новому симбіозу технологічних, соціальних і фінансових інновацій.

Вищевикладене дозволяє стверджувати, що формування нової моделі фінансових відносин в умовах сталого розвитку має здійснюватися також 3 урахуванням принципу конвергениї, що разом і коллаборацією може створити суттєвий синергетичний ефект.

Досліджуючи зміну моделі фінансових відносин та ролі фінансового капіталу внаслідок розгортання парадигми сталого розвитку вважаємо за корисне екстраполювати результати дослідження К. Перес щодо технологічної парадигми, яка зазначає, що «розвиток і поширення кожної технологічної революції стимулює інновації у області фінансів, а потім дозволяє пожинати плоди від використання нових інструментів, породжених фінансовим капіталом» [16], і далі: «фінансовий капітал стимулює кожну технологічну революцію у непря-мій, але надзвичайно важливій формі: він стає одним із самих сміливих і готових на все клієнтів для ії продукції і послуг» [16]. На наш погляд, ці висновки справедливі для життєвого циклу усілякої парадигми, і нинішній етап розвитку фінансових відносин та поведінки фінансового капіталу в умовах розгортання парадигми сталого розвитку $є$ тому підтвердженням. Наслідуючи логіку Перес щодо розуміння синергії як «поєднання 3 метою розповсюдження»[16] можна стверджувати, що пози-тивні інтерналії парадигми сталого розвитку як то симбіоз економічних, соціальних i екологічних компонент створюють синергетичний ефект, який дозволить монетизувати нефінансові чинники i протягом певного часу отримувати фінансові вигоди.

\section{5. Висновки}

За результатами дослідження можна зробити висновок, що в результаті розгортання парадигми сталого розвитку відбуваються зміни у фінансових відносинах, які набувають характеру системних i перетворюються в закономірності їх розвитку. До основоположних принципів формування нової моделі фінансових відносин у умовах сталого розвитку слід віднести:

1) принцип соціалізації;

2) принцип коллаборації за засадах суспільної солідарності;

3) принцип демократизації;

4) принцип конвергенції. 
На наш погляд, трансформація фінансових відносин на нинішній стадії розвитку постінду-стріальної економіки і укорінення парадигми сталого розвитку знаходиться в перехідному періоді від етапу інтерформації, що характеризується нестійким та невизначеним станом, співіснуванням між формами, до етапу інтоформації, за якого відбувається набуття нової стійкості, нової форми. Поступово нова модель фінансових відносин набуває елементів цілісності, тобто якісно нової системи мотивації, соціальних зв'язків, принципів формування. Фінанси, як забезпечувальна ланка економіки, формуючи рефлексію у вигляді адекватної реакції на виклики сталого розвитку, по суті здійснюють інтерналізацію екстерналій.

\section{Лiтература}

1. Shiller, R. J. Capitalism and Financial Innovation [Text] / R. J. Shiller // Financial Analysts Journal. - 2013. Vol. 69, Issue 1. - P. 21-25. doi: 10.2469/faj.v69.n1.4

2. Гальчинський, А. С. Криза і цикли світового розвитку [Текст] / А. С. Гальчинський. - К.: АДЕФ Україна, 2009. - 392 с.

3. Зайцев, Ю. К. Сучасна політична економія (проблеми та інституціональне, поле предмета і методології досліджень) [Текст]: навч. посіб. / Ю. К. Зайцев, В. С. Савчук. - К.: КНЕУ, 2011. - 337 с.

4. Колот, А. М. Соціальна відповідальність: теорія і практика розвитку [Текст]: монографія / А. М. Колот, О. А. Грі-шнова та ін.; за ред. А. М. Колота. - К.: КНЕУ, 2012. $501 \mathrm{c}$.

5. Уманців, Ю. М. Корпоративні структури у глобальному конкурентному просторі [Текст]: монографія / Ю. М. Уманців. - К.: ННЦ IAЕ, 2012. - 410 c.

6. Сірко, А. В. Корпоративні відносини в перехідній економіці: проблеми теорії і практики [Текст] / А. В. Сірко . - К.: Імекс, 2004. -413 с.

7. Social Economy Alliance [Electronic resource] / Available at: http://www.socialenterprise.org.uk/policycampaigns/latest-campaigns/social-economy-alliance

8. Смысл социальных финансов в том, чтобы укрепить НКО // Деньги и благотворительность. - 2012. № 75 . - C. $4-10$.

9. Tencati, A. Towards a New Theory of the Firm: The Collaborative Enterprise [Text] / A. Tencati, L. Zsolnai // The Economic and Financial Crisis and the Human Person Von Hogel Institute (VHI) International Workshop. - St. Edmund's College, Cambridge, 2013. - 21 p.

10. Porter, M. Creating Shared Value: How to Reinvent Capitalism - and Unleash a Wave of Innovation and Growth [Text] / M. Porter, M. Kramer // Harvard Business Review. 2011. - Vol. 89, Issue 1/2. - P. 62-77.

11. Я сохраню, если ты сохранишь. Сохраним ли мы природные ресурсы [Електронний ресурс] / Режим доступу: http://econet.ua/articles/19915-ya-sohranyu-esli-tysohranish-sohranim-li-my-prirodnye-resursy

12. Исторический словарь галлицизмов русского языка / [Електронний ресурс] / Режим доступу: http://gallicismes.academic.ru/

13. Энциклопедия социологии [Електронний ресурс] / Режим доступу: http://dic.academic.ru/contens.nsf/socio/
14. Большой юридический словарь [Електронний pecypc]. - Режим доступу: http://jurisprudence.academic.ru

15. Cooperating with the future [Electronic resource] / Available at: http://www.nature.com/nature/ journal/vaop/ ncurrent/ full/nature13530.html

16. Перес, К. Технологические революции и финансовый капитал. Динамика пузырей и периодов процветания. Сер. «Современная институционально-эволюционная теория» [Текст] / К. Перес; пер. с англ. Ф. В. Маевского. - М.: Издательский дом «Дело» РАНиГС, 2011. $-232 \mathrm{c}$.

\section{References}

1. Shiller, R. J. (2006). Capitalism and Financial Innovation. Financial Analysts Journal, 69 (1), 21-25. doi: 10.2469/faj.v69.n1.4

2. Hal'chyns'kyj, A. S. (2009). Kryza i tsykly svitovoho rozvytku. Kyiv, Ukraine: ADEF-Ukraina, 392.

3. Zajtsev, Yu. K., Savchuk, V. S. (2011). Suchasna politychna ekonomiia (problemy ta instytutsional'ne, pole predmeta i metodolohii doslidzhen'): navch. posib. Kyiv, Ukraine: KNEU, 337.

4. Kolot, A. M. (Ed.) (2012). Sotsial'na vidpovidal'nist': teoriia i praktyka rozvytku. - Kyiv, Ukraine: KNEU, 501

5. Umantsiv, Yu. M. (2012). Korporatyvni struktury u hlobal'nomu konkurentnomu prostori. Kyiv, Ukraine: NNTs IAE, 410

6. Sirko, A. V. (2004). Korporatyvni vidnosyny v perekhidnij ekonomitsi: problemy teorii i praktyky. Kyiv, Ukraine: Imeks, 413

7. Social Economy Alliance. Available at: http://www.socialenterprise.org.uk/policy-campaigns/latestcampaigns/social-economy-alliance

8. Smysl sotsyal'nykh fynansov v tom, chtoby ukrepyt' NKO (2012). Den'hy y blahotvorytel'nost', 75, 4-10

9. Tencati, A. L., Zsolnai, L. (2013). Towards a New The-ory of the Firm: The Collaborative Enterprise . The Economic and Financial Crisis and the Human Person Von Hogel Institute (VHI) International Workshop. St. Edmund's College, Cambridge, 21.

10. Porter, M., Kramer, M. (2011). Creating Shared Value: How to Reinvent Capitalism - and Unleash a Wave of Innovation and Growth. Harvard Business Review, 89 (1/2), 62-77.

11. Ya sokhraniu, esly ty sokhranysh'. Sokhranym ly my pryrodnye resursy. Available at: http://econet.ua/articles/ 19915-ya-sohranyu-esli-ty-sohranish-sohranim-li-my-prirodnyeresursy

12. Ystorycheskyj slovar' hallytsyzmov russkoho iazyka. Available at: http:/gallicismes.academic.ru/

13. Entsyklopedyia sotsyolohyy. Available at: http://dic.academic.ru/contens.nsf/socio/

14. Bol'shoj iurydycheskyj slovar'. Available at: http://jurisprudence.academic.ru

15. Cooperating with the future Available at: http://www.nature.com/nature/journal/vaop/ncurrent/full/nature 13530.html

16. Peres, K. (2011). Tekhnolohycheskye revoliutsyy y fynansovyj kapytal. Dynamyka puzyrej y peryodov protsvetanyia. Moscow Russia: Yzdatel'skyj dom «Delo» RANyHS, 232.

Рекомендовано до публікації д-р екон. наук Гушко С. В. Дата надходження рукопису 15.01.2015

Васильчук Ірина Петрівна, кандидат економічних наук, доцент. кафедра фінансів, податків і страхової справи. Криворізький економічний інститут ДВНЗ «КНУ», пр. Карла Маркса, 64, м. Кривий Ріг, Україна, 50000

E-mail: vasylchuk-irina@rambler.ru 